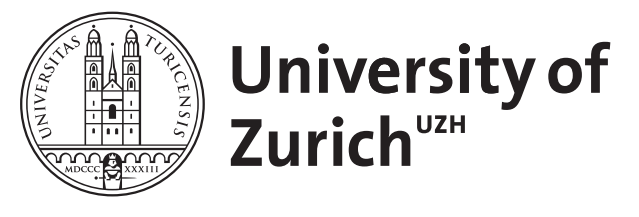

\title{
Historical Sociopragmatics
}

Leitner, Magdalena ; Jucker, Andreas H

\begin{abstract}
Historical sociopragmatics studies the social dimension of language use from a historical perspective. Like historical pragmatics in general, it must rely on written data (except for the very recent past), which poses some specific analytical challenges. In this contribution, we show how approaches to these challenges have developed in recent years. The research focus in historical sociopragmatics has followed the trend in sociopragmatics, where the earlier focus on a mapping between specific linguistic forms and specific pragmatic functions is increasingly extended to a wider consideration of the discursive nature of pragmatic entities whose function only emerges in the interaction between conversational partners. We illustrate such a discursive approach with an analysis of a sequence of letters from the Breadalbane Collection, 1548-83, in which leading members of a Scottish Highland clan negotiate their relationships, their respective roles and the wider impact of events that led to growing tensions between them.
\end{abstract}

DOI: https://doi.org/10.1017/9781108954105.035

Posted at the Zurich Open Repository and Archive, University of Zurich

ZORA URL: https://doi.org/10.5167/uzh-202783

Book Section

Accepted Version

Originally published at:

Leitner, Magdalena; Jucker, Andreas H (2021). Historical Sociopragmatics. In: Haugh, Michael; Kádár, Dániel Z; Terkourafi, Marina. The Cambridge Handbook of Sociopragmatics. Cambridge: Cambridge University Press, 687-709.

DOI: https://doi.org/10.1017/9781108954105.035 
Prepublication version of: Leitner, Magdalena, and Andreas H. Jucker. (2021) Historical sociopragmatics. In: Michael Haugh, Dániel Z. Kádár and Marina Terkourafi (eds.). The Cambridge Handbook of Sociopragmatics. Cambridge: Cambridge University Press, 687-709.

\title{
Historical Sociopragmatics
}

\author{
Magdalena Leitner and Andreas H. Jucker (University of Zurich)
}

\section{Introduction}

Sociopragmatics is particularly relevant for historical pragmatics because of the reliance of historical studies on contextual information. Historical pragmatics in general, as an independent subfield of pragmatics, started out in the last decade of the previous century when pragmaticists increasingly began to be interested in earlier stages of individual languages and when historical linguists started to develop an interest in pragmatic research questions. Jucker (1995) is an early collection of papers written partly by pragmaticists with a historical interest and partly by historical linguists with an interest in pragmatics. Most articles in that volume include social aspects of language use, as, for instance, Nevalainen and Raumolin-Brunberg's (1995) analysis of politeness phenomena and terms of address in private correspondence from the fifteenth to the seventeenth century with a careful consideration of the social standing and the personal relationships between the writers and recipients of these letters. With hindsight, such approaches can be classified as historical sociopragmatics. But there were also some contributions which focused on pragmatic developments independent of the social embedding (e.g. Schwenter and Traugott 1995).

In subsequent work in the area of historical pragmatics, there continued to be a tradition that relied more systematically on the social context of language use in earlier periods of specific languages and a tradition that focused more on the theoretical underpinnings of pragmatic aspects of language use in the past. These two traditions in historical pragmatics correspond to the traditions in pragmatics in general, called Continental European pragmatics and Anglo-American pragmatics (Huang, 2007: 4) or social pragmatics and theoretical pragmatics ${ }^{1}$ (Chapman, 2011: 5), respectively. It is probably fair to say that in historical pragmatics the Continental European or social tradition has always been stronger, not only in the early volume mentioned above but also in subsequent work over the past two and a half decades. Because of the widespread applications of context-sensitive approaches in historical pragmatics it has been argued that the prefix socio- is not needed to define the Continental European tradition as a subfield within the field (see Włodarczyk and Taavitsainen, 2017: 160). Nevertheless, the term historical sociopragmatics has gained currency in historical pragmatics. The label first came into prominence in a special issue of the Journal of Historical Pragmatics guest-edited and introduced by Culpeper (2009). ${ }^{2}$ This raises the question of how to position historical sociopragmatics within historical pragmatics. The Continental European tradition, although being dedicated to the social dimension, is not synonymous

1 The use of the label 'theoretical' seems rather unfortunate as it may wrongly imply that social pragmatics somehow lacks a theoretical foundation.

2 The issue was subsequently republished as an independent volume (Culpeper, 2011a). 
with historical sociopragmatics. The former still integrates the Anglo-American ${ }^{3}$ tradition, which examines language change at the semantic-pragmatic interface without locating the changes in the social and interactional context. Historical sociopragmatics, as it has been defined (e.g. Culpeper, 2010: 87, Marmaridou, 2011: 95-98), puts an even stronger focus on the specific social context of language use. Thus, the concerns of the Anglo-American tradition are in our view outside of the scope of historical sociopragmatics. The Anglo-American perspective is particularly evident in diachronic form-to-function mappings, that is, studies that take linguistic forms, such as discourse markers, as their starting point and examine their pragmatic developments over time (Jacobs and Jucker, 1995: 13-18). However, form-to-function mappings can be sociopragmatic if diachronic changes are embedded in their wider or more specific social and interactional contexts (e.g. Claridge, 2018, Lutzky, 2012). Historical sociopragmatics is not a question of whether the starting point of an investigation is a linguistic form or function but whether the social and situational context is systematically taken into account when analysing language use in the past and changes over time. ${ }^{4}$

Context in historical sociopragmatics can be conceptualised at different levels of granularity, as Culpeper has shown in several publications (2009, 2010 and this volume). Based on ideas first proposed in Culpeper et al. (2008: 320), he distinguishes between the micro level of the actual use and interpretation of speech acts and discursive practices; the meso level of situated interactions in specific activity types, frames or genres, and the macro level of socio-cultural phenomena relating to different cultures, nationalities or genders (Culpeper, this volume). The label historical sociopragmatics as we are going to use it in this contribution can be applied to studies on all these levels and thus covers a lot of research with a long history.

In the following, we will introduce some of the key concerns and concepts of historical sociopragmatics, which apply to historical pragmatics more generally, as, for instance, the issues of choosing suitable historical data, the units of analysis and the social dimension. Afterwards, we will give an outline of the discursive turn in historical sociopragmatics. We will illustrate the result of this turn and the new way of looking at data with a detailed analysis of a sixteenth-century letter exchange between members of a Scottish Highland clan. The analysis will show how the letter-writers negotiate their relationships and roles and the significance of the events that led to growing tensions between them.

3 Seminal publications on Continental European historical pragmatics include chapters on topics associated with the Anglo-American tradition, e.g. grammaticalization and pragmaticalization (e.g. Jucker and Taavitsainen, 2010, Jucker and Taavitsainen, 2013).

4 We take a different line here from Culpeper (e.g. 2010: 76-78) and Marmaridou (2011: 95-98), who define form-to-function mappings as pragmalinguistic approaches and function-to-form mappings and pragmaphilology as part of historical sociopragmatics. While we agree that pragmaphilology exemplifies historical sociopragmatics, the distinctions for diachronic pragmatics should be defined by the contextsensitivity of studies. For the general distinction between pragmalinguistics and sociopragmatics, see Culpeper (this volume). 


\section{Key concepts in historical sociopragmatics}

The first key concept that we want to introduce is the status of data in historical pragmatics. In the early days of historical pragmatics, in the 1990s, the status of the data that could be used for historical pragmatic investigation was a major issue and was regularly discussed in the literature, often in an apologetic way. In fact, entire papers were published that dealt exclusively with data problems in historical pragmatics (see Kytö, 2010 and references cited there). It was seen as a problem that for historical periods, apart from the very recent past, the researcher had to rely on written sources. Only a very small proportion of all the language produced in the past was written language and only a small part of the written records of the past has survived to the present day. Historical linguistics in general has been seen as an 'art to make the best use of bad data' (Labov, 1994: 11). This was felt to be even more true for historical pragmatics. The ideal in pragmatics, at that time, was still natural spoken interaction, and data that deviated from this ideal generally required extensive justifications. Preferred types of data for historical pragmaticists were therefore written texts that could be argued to be as close as possible to spoken language. Trial records were taken to be relatively faithful representations of words spoken in a courtroom even if the formality of the situation produced interactions that could not be taken to represent everyday conversation. Plays present language to be spoken on a stage with many pragmatically interesting features of interaction but they were seen as problematic because of their contrived and artificial nature. In real life, nobody speaks in iambic pentameters, for instance. Letters, and in particular private letters, were seen as interactive and personal and therefore as 'speech-like' but not as spoken language (Culpeper and Kytö, 2010: 17, original emphasis). As a result, historical pragmaticists regularly discussed the implications of what were seen as data limitations.

In recent years, however, attitudes towards different types of data have changed considerably. Pragmatics in general has moved away from considering spoken everyday interaction as the ideal or perhaps the only legitimate type of data and has increasingly recognised all kinds of language use and interaction as legitimate data for pragmatic research. Written language and even fictional language has come to be appreciated for what it is and not as an imperfect substitute of spoken interaction (Jucker and Locher, 2017: 4-6, Jucker and Taavitsainen, 2013: 25-26). Thus, an investigation of terms of address in a play by Shakespeare, to take just one example, is no longer seen as an attempt to get as close as possible to the everyday spoken language at the turn from the sixteenth to the seventeenth century but as an investigation of how Shakespeare chose to represent the use of address terms in the exchanges between his fictional characters. As a result, pragmaticists have to be more modest. The claims based on their research cannot easily be generalised beyond the specific data of the investigation. But at the same time, there is no need anymore to apologise for specific data choices. On the contrary, different types of data add to an appreciation of the boundless variability and diversity of language use.

The second important concept to be briefly introduced is the unit of analysis. Initially the focus of historical pragmatics was generally on specific linguistic elements that were pragmatically significant, such as discourse markers, terms of address and speech acts. Good examples of early book-length studies of such elements are Brinton (1996), Busse (2002) and Arnovick (1999). Brinton (1996) investigated discourse markers, or pragmatic 
markers as she called them, such as gan, anon, hwat or I gesse in the history of English. Busse (2002) investigated terms of address (ye and thou and their morphological variants) in Shakespeare's plays; and Arnovick (1999) traced the histories of seven speech acts, such as insults, promises, or curses in the history of English. The extent to which these works consider the social context in which the investigated elements are being used varies considerably, and thus it is not always easy to assign them clearly to historical sociopragmatics or to historical theoretical ${ }^{5}$ pragmatics. Brinton and Arnovick are both primarily interested in the theoretical processes of grammaticalization, pragmaticalization and discursization (i.e. the ways in which lexical material in the course of time comes to serve grammatical, pragmatic or discourse functions), while Busse is more interested in the social relationships between the fictional characters in Shakespeare's plays and how these relationships influence their language use.

Some other early work focused on issues of politeness and impoliteness. It did not take long for the ground-breaking work by Brown and Levinson (1987) to be applied to historical data. Brown and Gilman (1989) tested their politeness theory on four major tragedies by Shakespeare, and Kopytko (1995) extended their work with an additional four comedies and more sophisticated statistics. Nevala (2004) used the same framework for her research on terms of address in Early English correspondence. Culpeper (1996) developed a mirror-image impoliteness theory, which he applied in a qualitative case study to Shakespeare's Macbeth. In all these cases, taking Brown and Levinson as a lead, the analysis focused on specific linguistic forms and strategies to which specific politeness, or - in the case of Culpeper - impoliteness, values were assigned. Indirect formulations, such as could you please, or the use of honorifics (e.g. titles of courtesy, such as your Ladyship) were seen to carry specific politeness values.

In more recent work in historical pragmatics the unit of analysis has often been extended. The focus is no longer on an isolated element, such as terms of address or discourse markers, but on communicative practices which can be understood as conventionalised ways of carrying out a communicative task (Jucker, 2017: 557). Such tasks can be relatively small, as for instance in the task of entering into a conversation (a greeting), but they can also be larger, as for instance cross examinations in courtrooms (e.g. Archer, 2005, and her subsequent publications). The largest units are genres and types of discourse, with investigations into their macrostructures and 'meaning-making practices' (e.g. Taavitsainen, 2017: 253). These units - whether small or large - can be understood as more or less conventionalised solutions to specific tasks, and crucially they must be analysed in their wider contexts and with due consideration of their status as being partly conventionalised and partly re-negotiated every time they are being used.

\section{The discursive turn in historical sociopragmatics}

In this section, we describe what we would like to call the discursive turn in historical pragmatics. It is a development that has been noted and described for approaches on politeness and impoliteness, but we want to argue that this development can also be observed in historical pragmatics and especially in historical sociopragmatics. In section 3.1, we briefly sketch the theoretical background to this development, and in section 3.2, we will provide a case study to demonstrate how such an approach focuses on the

5 See footnote 1 above. 
interaction in an analysis of a letter exchange between principal members of a Scottish Highland clan of the sixteenth century.

\subsection{Theoretical Background}

Grainger (2011) describes the development of politeness scholarship in terms of three waves (see also Culpeper and Hardaker, 2017: 206-208). In the first wave, which she calls Gricean approaches, investigations into politeness were very much modelled on second-order politeness, in particular on the work by Brown and Levinson (1987). Impoliteness was seen - in some sense - as the 'flip-side' or the opposite of politeness. The second wave, called postmodern or discursive approach, focused on participants' evaluations of (im)politeness in interaction. It moved away from speaker intentions and theoretically conceived conceptualisations of politeness (or impoliteness) and concentrated on the lay-person's conceptualisations of these concepts, i.e. first-order politeness. Values of politeness or impoliteness were argued not to be inherent in specific linguistic elements but to be discursively negotiated between the participants. The third and current wave, called sociological or interactional approaches by Grainger (2011), encompasses what can be seen as a rapprochement between the two previous approaches. It takes the speaker and the hearer equally into consideration and examines the management of interpersonal relationships in interactions and their sequential organisation. It maintains the discursive concern for participants' evaluations of (im)politeness but also allows for conventionalised and therefore relatively stable politeness or impoliteness values of specific linguistic forms.

We find it useful to extend the metaphor of the three waves to the developments in historical sociopragmatics. It is important to stress, however, that the differences between the three waves are not clear-cut (see Culpeper and Hardaker, 2017: 208). They are more a matter of emphasis and focus.

The first wave, or early phase, of historical sociopragmatics was characterised by a focus on the mapping of specific linguistic forms to specific communicative functions or vice versa. In fact, overviews of research at that time regularly categorised different approaches on the basis of whether they started with a specific linguistic form and investigated how their functions changed over time, the so-called form-to-function mapping; or whether they started with a specific communicative function and investigated the various linguistic forms with which it could be performed, the so-called function-to-form mapping (see Jacobs and Jucker, 1995, who were probably responsible for introducing these terms). Much of the early work in historical sociopragmatics can easily be classified according to this distinction. While many form-to-function mappings do not pay much attention to the social context of language use, there are early studies that investigate the diachronic functional shifts of linguistic forms from a sociopragmatic perspective. Busse (2002), for instance, starts with second person pronouns in Shakespeare's plays and investigates their functional profiles in connection with the genre context and social parameters of the interlocutors. Examples for function-to-form mapping are Jucker and Taavitsainen's (2000) diachronic study of insults in the history of English and Culpeper's (1996) investigation of the linguistic elements that are used to express the communicative function of attacking face.

The second wave, or discursive approach, rejected the simple mapping patterns of the first wave and argued that linguistic elements cannot be assigned any inherent meaning 
values. Such values only emerge in the interaction between participants. In other words, they are always discursively negotiated. The focus shifted away from the speaker to the communicative interaction. This trend was particularly noticeable in the area of (im)politeness work. Discursive (im)politeness researchers - in particular Eelen (2001), Mills (2003), and Locher and Watts (2005) - were critical of earlier politeness work and argued strongly for a more comprehensive view in which politeness and impoliteness were no longer seen as mirror images of each other but as behaviours on a continuum of interaction that also includes less marked forms of behaviour. Furthermore, they argued for a shift away from academically defined concepts of different types of behaviour to everyday conceptualisations and discursive negotiations of such behaviour.

The discursive approach has gained ground in historical sociopragmatics. In the subfield of historical (im)politeness studies, historical texts have been analysed without imposing any pre-existing notions of (im)politeness. Instead, (im)politeness values are reconstructed through examining participants' interactive negotiations of meanings, for example, in the fictional dialogues of medieval romance (Jucker, 2014), or participants' ritual use and exploitations of conventionalised linguistic strategies in letter-writing (e.g. Bax, 2010, Kádár, 2010). Discursive investigations have become established beyond historical (im)politeness. Petikó (2017), for example, analyses how participants in eighteenth-century Hungarian witchcraft trials discursively construct witchcraft identities and communities. Moreover, discursive approaches have been developed and applied in historical speech-act research, for example, to examine participants' negotiations of speech-act functions in trial proceedings (Leitner, 2017) or participants' use of speech acts to exercise power in parliamentary debates (Reutner, 2016). A discursive turn may also be noted in a broader sense, namely in the recent revival of philology in historical sociopragmatics as a means of examining the material dynamics of text production and reception from the perspective of the participants involved in these processes (Włodarczyk and Taavitsainen 2017: 164-165, see Section 4 'Recent trends' below).

In a wider sociopragmatic context, the trend away from speaker-produced pragmatic units to interactions between speakers and hearers can be exemplified by the papers in a volume devoted to a range of different communities of practice (Kopaczyk and Jucker, 2013). A community of practice is seen as a group of people with a common purpose who share linguistic resources for their specific communicative needs. A focus on such communities, it is argued, provides a new perspective on the social processes involved in language change. Cruickshank (2013), for instance, examines a group of eighteenthcentury Scottish letter-writers and how the epistolary exchange contributed to the emergence of Scottish Standard English. Her analysis shows that a Scottish aristocrat's use of Standard English - the prestige variety - was interspersed with Scotticisms, which reflected the communicative needs when writing to members of his local network.

The second wave in historical sociopragmatics is further attested by investigations into metacommunicative expressions, in other words, how participants talk about (im)politeness, speech acts or other aspects of communication. Metacommunicative expressions are the focus of all contributions in Busse and Hübler's (2012) edited volume. A more recent example is Sairio's (2017) study of lexemes associated with the concept of shame in eighteenth-century letters. Her results show that explicit terms of shame occur in formulaic apologies in situations of a perceived breach of social conventions, whereas direct expressions of shame are rare when correspondents talked 
about situations with a high risk of inducing shame, which suggests emerging taboo connotations of shame.

The third wave, as mentioned above, can be seen as a rapprochement between the first and the second wave. In such a view, the second wave is a strong version of a discursive approach, i.e. one which suggests that linguistic elements do not have inherent meanings. All meanings are always negotiated in a discursive process by speaker and addressee. It is doubtful whether there are any researchers who maintain a strong version of a discursive approach, but the third wave pays more systematic attention not only to the dynamics of the interaction (as defined above) but also to 'more stable meanings arising from particular linguistic forms' (Culpeper and Hardaker, 2017: 208). Culpeper and Hardaker (2017: 210) propose the notion of conventionalised expressions or routinised formulae to capture relatively stable politeness or impoliteness values for specific linguistic forms while still allowing for discursive adjustments or re-negotiations of these values in specific interactions. Culpeper (2011b: Chapter 4) offers an empirical, corpus-based, method to retrieve such formulae.

In historical sociopragmatics, third-wave approaches are just emergent. Jucker (2012), for example, shows how an analysis of the deception and intrigue depicted in Ben Jonson's Volpone, Or the Fox requires both default values and discursively negotiated values. The characters treat each other with superficially exceedingly polite and polished language, which is used to hide their underlying devious motives and intentions. Włodarczyk (2013) combines a first-order with a second-order approach in her study of nineteenth-century British colonial office correspondence to examine the letter as an analytic category from different angles. She concludes that neither approach on its own can fully conceptualise letter-writing in the past. Leitner (2015) applies the interactional focus of the third wave to sixteenth-century Scottish correspondence and examines how participants managed individual and collective aspects of their social roles and relationships in conflicts across sequences of letters.

The following case study illustrates key topics of third-wave sociopragmatics. The approach on historical letter-writing uncompromisingly considers not just the production side of language use but the interaction between writers and readers who take turns in adopting these roles. It demonstrates the way in which linguistic expressions have default meanings that are also regularly negotiated and the implications of these negotiations on the relationships and status of the participants and the groups that they represent.

\subsection{Case Study}

The present case study focuses on a sequence of four letters from the Breadalbane Collection, 1548-1583 (Dawson, 2004/2007), a manuscript-based online edition of Scottish correspondence that offers rare insights into sixteenth-century Highland clan management (Dawson, 1997: 1-2). The selected sequence of letters gives evidence of a multi-layered conflict, which starts out as a skirmish between two clans, the Campbells and the Buchanans, whose chiefs were allies. Figure 1 gives an overview of the clans involved in the conflict, or mentioned in the exchange, and their leading figures. 


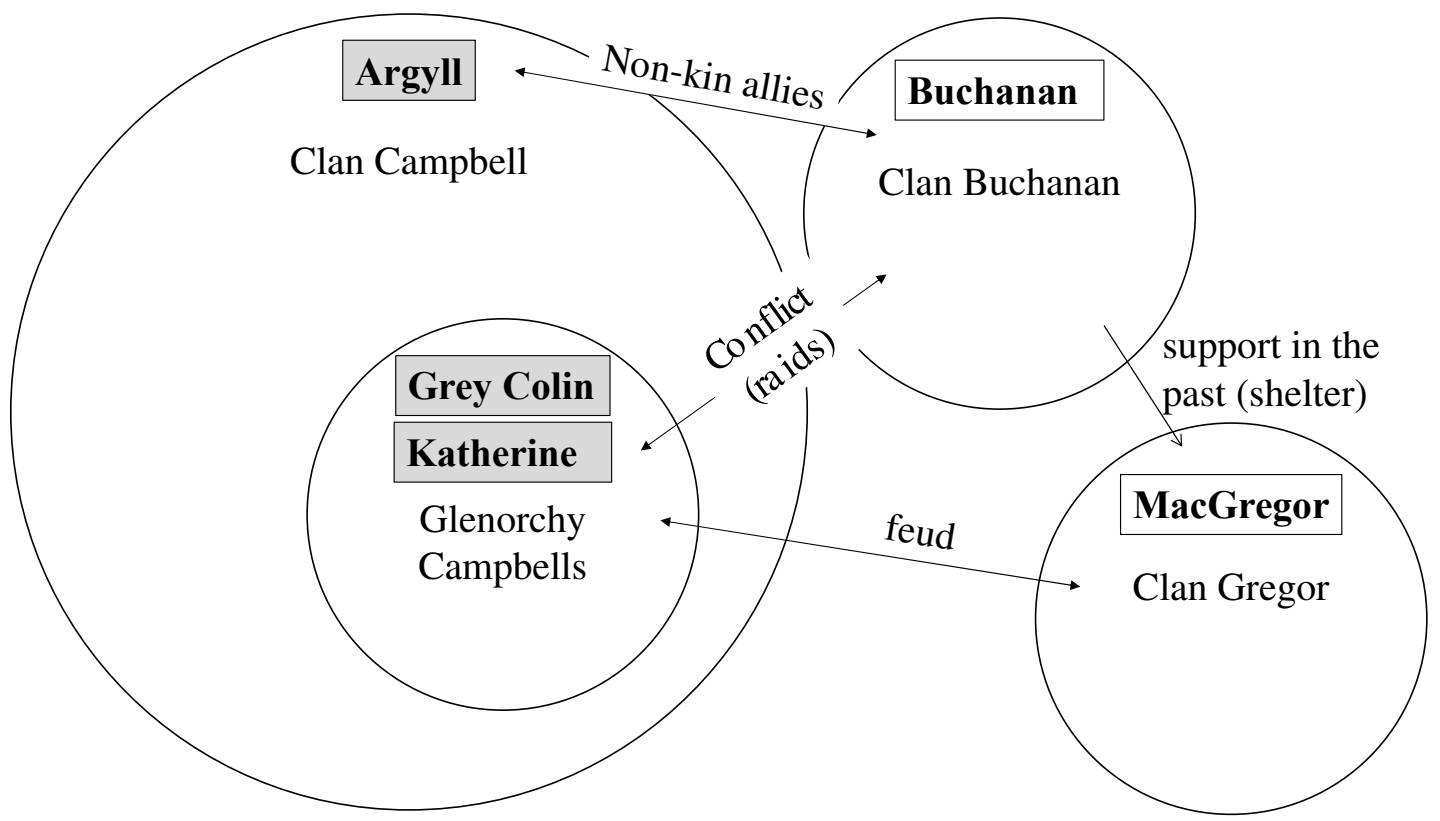

Figure 1: Relations between clans and their leaders in the Campbell-Buchanan conflict (shaded text boxes indicate participants involved in the letter-writing exchange).

The chief of Clan Campbell - Archibald Campbell, the $5^{\text {th }}$ earl of Argyll (henceforth Argyll) - initiated the letter exchange to settle the conflict, which in turn triggered an internal clan dispute between Argyll and one of his most trusted principal members, Colin Campbell, the $6^{\text {th }}$ laird of Glenorchy (henceforth Grey Colin, according to his nickname, Dawson, 1997: 14). Argyll was told that some of Grey Colin's men had raided the lands of Clan Buchanan and killed a man there. The complaint was made by George Buchanan (henceforth Buchanan), laird and head of Clan Buchanan, whose territories were in The Lennox, a neighbouring area to the Glenorchy lands in Breadalbane (Keay and Keay, 2000: 114). There are no letters between Argyll and Buchanan in the Breadalbane Collection. It is not clear how Buchanan informed Argyll about the raid, whether in writing or in a personal meeting, which in sixteenth-century Scotland was still preferred over written correspondence (Dawson, 1997: 4). The purpose of Argyll's first letter was to find out if Buchanan's report was true, and if so, to admonish Grey Colin that the raided goods should be restored to the Buchanans (MS NRS GD112/39/3/24). Grey Colin was offended by his chief's letter. In his reply, he criticised Argyll for favouring Buchanan over his most loyal kinsmen (Example (1)):

(1) I am glaid yat zour lordship be servit be boquhennan and siclik honest men nochttheles | it is na caus to zour lordship to lychlie zour awin quhilk man be zour best quhen it cummis to ye vpwith For my forbearis servit zour lordshipis predecessouris quhen the | boquhennanis wer to seik and speciallie quhen yair wes mayst ado 'I am glad that your Lordship is served by Buchanan and such honest men; nonetheless, it is no reason to your Lordship to despise your own [i.e. your 
kinsmen] who are obliged to be your best when difficulties arise. Because my ancestors served your Lordship's predecessors when the Buchanans were not to be found and especially when there was most to do.'

(MS NRS GD112/39/5/2) ${ }^{6}$

Apparently, Grey Colin felt his position and the status of his kin group within Clan Campbell to be threatened by his chief's letter. The wording of Argyll's first letter suggests instead that he put more trust in Grey Colin than in Buchanan's report (Example (2)):

(2) And yis we beleif nocht nor will bel[eif that] zour dewyiss nor consall was <deletion> at yis deid doyng be [rassone] ze maid us na maner of advertisiment 'And this [i.e. the report about the raids] we do not believe nor will believe that your design or counsel was in this act of violence because you gave us no notice of any kind'

(MS NRS GD112/39/3/24)

A discursive close reading of the letter sequence helps to understand Grey Colin's reaction and the delicate situation in which Argyll found himself as mediator in this conflict.

Notably, Argyll's affirmation of trust in Grey Colin is preceded by a praise of Buchanan's loyalty and an implicit threat (Example (3)):

(3) And he hes de

pendit wpoun us and dois 3 it And hes refusit and refussis

ony oder to his maister bot us onlie [....]

And we knaw weill yat ye saidis laird

and his freindis wilbe als radelie to put lat/ all ye clangregour

at our command as ony off our avyn kynnismen or servanttis

And yairfoir ze sall wnderstand yat yairis na man yat will

offend or do skayth to ye saidis laird He offerand ye thyng yat

is werie guid and rasonabill bot quhateuer yai be yat dois

ye saymin we will nocht hald yame na odervayis to us nor the clangregour

'And he [i.e. Buchanan] has depended on us and still does. And [he] has refused and refuses any other as his master except us only [....] And we know well that the said Laird [i.e. Buchanan] and his friends will be as ready to put all the Clan Gregor at our command as any of our own kinsmen or servants. And therefore, you shall understand that there is no man that will offend or do harm to the said Laird. He is offering the thing that is very good and reasonable but whoever they

6 Editing principles for letter excerpts follow Smith's (2012: 71-74) transcription policy for Older Scottish texts. Modern English translations of cited examples are based on the Dictionary of the Older Scottish Tongue (DOST) and the Oxford English Dictionary (OED). 
are who do the same [i.e. offend/attack Buchanan] we will hold them to us in no other ways than the Clan Gregor.'

(MS NRS GD112/39/3/24)

We will examine each of these discursive moves in turn to trace how they afforded the responsive act of taking offence. The emphasis on Buchanan's allegedly undivided loyalty served to foreground Argyll's obligations of lordship over the Buchanans. The Buchanans were bound to Argyll in manrent, which was an important social contract. It consisted of a written agreement that specified obligations of loyalty and protection between the Buchanans as a satellite kin group and Argyll as their lord (Cathcart, 2006: 86, Dawson, 1997: 43). According to Argyll, Buchanan fulfilled his part of their social contract by promising to put any of his men who were found guilty of raiding Grey Colin's territories under Argyll's judicial authority. Buchanan's readiness to serve Argyll extended to helping with persecuting the Clan Gregor, who were in a feud with the Glenorchy Campbells (see Figure 1 above, Dawson, 1997: 55-59).

What stands out in Argyll's letter is his comparison of Buchanan's support to that of his 'own kinsmen' (Example (3) above). This praise evokes the highest level of trust by means of the default value of kinship. Blood relations in sixteenth-century Scotland were regarded as the strongest and closest relationships, which made obligations of mutual support most compelling (Dawson, 1997: 9-12). There is no evidence of kinship between Argyll and Buchanan, even though Argyll referred to Buchanan as our servitour and $\mid$ cousyng 'our servant and cousin' (MS NRS GD112/39/3/24). Cousin could be used as a term of extended kinship, a social practice rather common at the time to claim a closer relationship than existed (Dawson, 1997: 10). By placing Buchanan's non-kin, contractbased, loyalty on the same level as kinship, Argyll exploited the default value of kinsmen to claim the closest in-group relationship with Buchanan, which in turn warranted the highest responsibility of protection and served to justify his intervention in the conflict.

Moreover, Argyll implicitly framed Grey Colin and the Glenorchy Campbells as his enemies. He threatened to attack anyone involved in the raid and murder on Buchanan's lands and announced that he would consider them 'in no other ways than the Clan Gregor' (Example (3) above). As Leitner (2015: 134) notes, '[b]eing associated with the Clan Gregor would mark anyone at that time as an enemy to Argyll, because the MacGregors were seen by the Campbells as the rebel clan who defied the lordship of their superiors, Grey Colin and Argyll (Dawson, 1997: 55-56).' The threat included Grey Colin's men and by implication Grey Colin himself. Grey Colin was held responsible for the reported raid of his men, according to the collective responsibility of landlords for their inferiors (see Cathcart, 2006: 52). Albeit implicit, Argyll's threat worked as an impoliteness formula (see Culpeper, 2011b: 136), which is indicated by Grey Colin's 'offensive counter' (Bousfield, 2008: 193) as he retaliated with a complaint (Example (1) above).

What Argyll communicated as a justification for acting in his social role of lordship was understood by Grey Colin as a threat to his privileged position within Clan Campbell. The Glenorchy Campbells, of whom Grey Colin was the head, were a cadet branch descended from the house of Argyll (Dawson, 1997: 9). Thus, they were bound to the chief by kinship. Grey Colin was one of the members of the chief's fine, i.e. a core circle who stood hierarchically just below the chief. Fine members were heads of cadet 
branches and heads of minor clans under the chief's lordship. They were the chief's counsellors and assisted him in managing the clan (Cathcart, 2006: 75-78). In his reply to Argyll's letter, Grey Colin complained that his chief despised his best kinsmen - by implication, Grey Colin and the Glenorchy Campbells - and overvalued Buchanan's loyalty (Example (1) above). His complaint indicates that Argyll's letter went against his expectation to be acknowledged as a core member in the chief's social network. He perceived himself and his house to be pushed to the edges while Buchanan had been raised to the chief's inner circle.

Correspondents' negotiations of relationships within the clan can be described in terms of Bucholtz's (1999) concepts of association and dissociation. Associative identity claims ${ }^{7}$ comprise linguistic devices ${ }^{8}$ by which participants assert closeness with in-group members and define what unites them as a group. Devices employed by participants 'to distance themselves from a rejected identity' and define what separates them 'from other groups and their values, behaviours, etc.' are called dissociative identity claims (Bucholtz, 1999: 211-212). As demonstrated by Kádár et al. (2013), Bucholtz's (1999) categories enhance discursive investigations of face in intergroup and intra-group interactions. Applying Bucholtz's (1999) approach to historical data requires the integration of period- and context-specific notions of hierarchy and power, as these aspects are not discussed in her framework.

Key values that determined in-group status in Scottish clans were kinship and loyalty shown to superiors (Cathcart, 2006: 25-26, Dawson, 1997: 8-11). The value of kinship was changing in the sixteenth century. As kinship by blood was not always sufficient to achieve clan cohesion, extended forms of kinship, such as marriage alliances and 'fictive kinship' created through fosterage or bonds of manrent, gained importance in strengthening group relations (Cathcart, 2006: 25-26, 90). Argyll's and Grey Colin's letters present a case-in-point for the negotiability of in-group relations. Both drew on the default value of kinship but in different ways. Argyll acknowledged Buchanan as a core member of his group by evaluating his non-kin, contractual, loyalty as kin-like (Example (3) above). Grey Colin contested this definition of core group status by foregrounding kinship combined with generational loyalty (Example (1) above). The Glenorchy Campbells also had a bond of manrent with the house of Argyll (Campbell, 2002: 6). It seems noteworthy that Grey Colin did not mention this social contract - although he referred to written agreements in other epistolary conflicts with his chief - but asserted closeness to the chief solely on the grounds of the traditional values associated with blood kinship. In a move of dissociation, he challenged Argyll's praise of Buchanan by reminding his chief of Buchanan's lack of loyalty in the past. Thus, he claimed a more peripheral position for his rival in the chief's network. Buchanan was indeed not always as loyal as Argyll claimed him to be: he and his clan were known for offering shelter to

7 Instead of Bucholtz's (1999: 211) terms 'NEGATIVE [... and] POSITIVE IDENTITY PRACTICES', we adopt Kádár et al.'s (2013: 347) renamed labels: associative/dissociative identity practices. However, we prefer the term claim instead of practice. Practice has been restricted by Bucholtz and Hall (2004: 377) to habitual behaviour, while claim comprises habitual and strategic behaviour.

8 People construct identities and group membership not only through language but also through other means, such as dress or leisure activities (Bucholtz, 1999: 213). The focus in this case study, however, is on language. 
the MacGregors, thereby supporting the enemies of Clan Campbell (Dawson, 1997: 43, see Figure 1 above). It is possible that Grey Colin's expression 'Buchanan and such honest men' was meant ironically (Example (1) above). Grey Colin's complaint about being despised by his chief suggests that the perceived offence was not only about expected rights and obligations, but also about positive values attributed to in-group relations, and thus a face ${ }^{9}$ threat. Since he was acting as representative of his house, his negotiation of in-group relations also had collective implications.

The face threat perceived by Grey Colin was probably aggravated by Argyll's implied threat. Being associated with an out-group like the MacGregors functions as dissociation. Argyll's implicit distancing from the Glenorchy Campbells might have been intended as a warning that they would no longer be entitled to their chief's protection but would have to face punishment if Buchanan's report were true.

Argyll's affirmation of trust (Example (2) above) was not enough to mitigate the threat to Grey Colin's face. Affirmations of trust seem to have been a conventional feature of conflict letters at the time. They 'consist of an epistemic verb phrase such as $I$ believe followed by asserting the other person's conformance to social norms or a denial of his or her violation of those norms' (Leitner, 2015: 104). Further evidence from the Breadalbane Collection and other sixteenth-century Scottish correspondence shows that affirmations of trust were not perceived as 'a genuine expression' of one's trust in the addressee (Leitner, 2015: 109-119). Although employed as mitigation strategies in conflict letters, they appear to have been conventionalised to such a degree that they were no longer powerful enough to neutralise impoliteness formulae such as Argyll's implied threat.

The sequentiality of praising Buchanan, implicitly threatening Grey Colin but then affirming trust in him reflects on the risks at stake for Argyll as mediator in this conflict. The chief had to balance the conflicting obligations of his role of lordship. On the one hand, he had to act as protector of the Buchanans. In his second letter to Grey Colin, Argyll expressed his concerns that Buchanan would cancel their alliance and make an official complaint at the royal court about Argyll's failure to keep law and order in his territories (Example (4)):

(4) And yat

haiffing Irespect/ to zour honour yat ye said laird suld nocht haif occasioun to complene vpoun zow to ye quenis maiestie for we wald nocht yat zour serwantis or ony yat dependis vpoun zow suld incur sik bruit And ye laird of boquhannan said planlie yat gif he hald dependit vpoun ony vyer except ws yat his guidis or geir wald nocht be tane away but law or ordour.

'And that having respect to your honour that the said Laird [i.e. Buchanan] should not have occasion to complain about you to her Majesty the Queen because we

9 Face in this case study is defined as a first-order concept. It concerns participants' perceptions of sensitive aspects of identity and social relationships which are negotiated by participants in interaction. The definition is based on Culpeper's (2011b) and Spencer-Oatey's (2002, 2005, 2007) concept of face (and references there cited), but also extended to account for the collective dimensions of face in sixteenthcentury Scottish correspondence (see Leitner, 2015 for further discussion). 
would not want that your servants or any who depend on you should incur such rumours. And the Laird of Buchanan said plainly that if he had depended on any other except us that his goods or possessions would not have been taken away but [there would have been] law and order.'

(MS NRS GD112/39/3/26)

Buchanan held Argyll responsible for the raid and saw him as incapable of fulfilling his duties of lordship. His criticism must have been a heavy blow on those aspects of Argyll's face that were defined by his social role. On the other hand, Argyll had to secure Grey Colin's loyalty. Argyll needed the support of his cadet heads to maintain his power of lordship (Dawson, 1997: 38). Cadet branches could break off from the parent clan, either by submitting themselves to the lordship of another chief or by becoming independent, especially if they thought that the chief was not fulfilling his role (Cathcart, 2006: 133-134, 216). In a later conflict with his chief, Grey Colin did exert pressure on Argyll by announcing that he would seek support elsewhere (MS NRS GD112/39/12/13). Thus, there was a potential risk for Argyll of losing Grey Colin and his cadet branch, next to the risk of losing the Buchanans as allies and the risk of face damage for the chief himself as a representative of his clan.

Argyll responded to Grey Colin's complaint with a 'defensive countermove' (Bousfield, 2008: 198) of explaining the motivation behind his first letter. He wrote a second letter to Grey Colin and a letter to Katherine Ruthven, Grey Colin's wife. Katherine played an active part in handling the affairs of the Glenorchy Campbells (Dawson, 1997: 22-26). Her inclusion in this letter exchange indicates that Argyll attributed to her a significant role of being a mediator in the interpersonal conflict between him and Grey Colin. In both letters, Argyll emphasised that he had written to Grey Colin out of concern for his cadet head (Example (4) above, Example (5)):

(5) And in deid we wald be leathe to heir ony thing yat war dishonour to him bot we wald advertis him yairoff [....] we will performe ye samin to our awin honour and his honor and ye weill of his houss And gif ye laird be nocht content yat we advertist him of ye bruit yat we hard we sall nocht writt to him agane in sik ane maner for trewlie it was for his awin honour and weill and es shewing of ewill bruit yat we wret to him and for vyir causs quhilk we think to be our dwete 'And it would indeed be hateful to us to hear anything that were dishonour to him [i.e. Grey Colin] but we would inform him about it. [....] We will perform the same to our own honour and his honour and the wellbeing of his house. And if the Laird [i.e. Grey Colin] may not be content that we warned him about the rumours that we heard, we shall not write to him again in such a way, because truly it was for his own honour and wellbeing and keeping clear of evil rumours that we wrote to him and for other reasons which we think to be our duty.'

(MS NRS GD112/39/3/27) 
At the heart of Argyll's expressed concern was the reputation of Grey Colin, himself and the whole clan, as reflected in his repeated use of (dis-)honour. As one of the core social values of early modern Highland clans, honour was intertwined with kinship and hierarchy and had individual as well as collective dimensions (Dawson, 1997: 8). It was a face sensitivity for those of superior status. At the individual level, it projected default expectations of fulfilling one's responsibilities as lord/laird towards one's kin group and vassals. The honour of individuals, however, was also determined by the behaviour of their inferiors. Moreover, kin groups had collective honour, which depended on the actions of individual group members or the whole group (Dawson, 1997: 8, 12-13, 1999: 237). This interweaving of individual and collective aspects is reflected in Argyll's letters. His use of possessive determiners, e.g. 3our/his (awin) honour 'your/his (own) honour' (Examples (4) and (5) above), indicates that he ascribed honour to Grey Colin as an individual representative of the Glenorchy Campbells. Grey Colin's honour was impugned by the actions of his men. In his reply to Argyll's first letter, Grey Colin acknowledged to have given the orders for the attack on Buchanan's territories but clarified that his men only confiscated the goods that one of Buchanan's men had previously stolen from the Glenorchy Campbells. Additionally, Grey Colin defended his honour by telling his chief that he had his attack legitimised by a royal commission (MS NRS GD112/39/5/2). Through the epistolary interaction, Grey Colin's honour was coconstructed as somehow separate from the honour of his chief, yet nonetheless connected to it. To Katherine, Argyll explained that his motivation was to save our awin| honour and his [i.e. Grey Colin's] honor and ye weill of his houss (Example (5) above). Evidently, Argyll felt his own honour as representative of Clan Campbell to be threatened by Buchanan's report of the raid and the abovementioned consequences on Argyll's reputation of lordship. Argyll's use of first-person plural pronouns conveyed the collective aspects of his face defined by his social role of lordship and at the same time the group face ${ }^{10}$ of Clan Campbell, which by implication had also been damaged by the rumours about the raid. His status as a magnate allowed Argyll to choose between singular and plural pronouns for self-reference. An important factor encouraging the use of the so-called royal we was probably the employment of amanuenses for writing his letters (Leitner, 2015: 131); however, mixed pronoun usage in some of his letters suggests that the choice of $I$ and we had additional pragmatic functions, such as distinguishing between matters that concerned him as an individual and matters of his role as a group representative.

This case study demonstrates the potentials of historical sociopragmatics in its richly contextualised analysis of language use in the past. In line with the third wave, it has examined how the sequentiality of discursive moves in a letter and their conventionalised meanings could prime certain readings. It was shown that participants discursively evoked the default values of kinship and loyalty to claim and contest their roles and positions in clan networks. The conflict letters reflect the multiple, interconnected, levels of honour, ranging from individual to group-based face sensitivities.

\section{Recent Trends}

\footnotetext{
${ }^{10}$ See Kádár et al. (2013) for the concept of group face as distinct from individual face.
} 
Recent work in historical sociopragmatics has been dominated by several different trends. There has been the move to more discursive approaches, which we have described and illustrated in this article. As a result, recent work increasingly focuses on the complexities of interaction between speakers and writers and their (sometimes complex) audiences rather than on speaker meanings alone. In addition, there are two trends that - at first sight - seem to be contradictory. On the one hand, scholars search for larger generalisation, which leads to larger and also to more specialised corpora. On the other hand, they search for richer contextualisation, i.e. a richer understanding of the specific circumstances in which language is being used, including not only the textual and situational context but also the material context. In the former case, they opt for the wide lens angle to see the larger picture; in the latter case, they opt for the microscope to detect the minute details. In both cases, they are driven by a desire for a deeper understanding of language use in social contexts in the past, and in both cases increased computer capabilities are a driving force behind some of these advances as we will briefly show below.

The last ten to twenty years have seen unprecedented progress in the development of both ever larger and ever more specialised corpora. More mega-size corpora have recently become available not only for present-day data but also for historical material (the Corpus of Historical American English (COHA), the Corpus of Late Modern English Texts (CLMET), the Old Bailey Corpus), and some present-day corpora include a historical dimension (e.g. the Corpus of Contemporary American English (COCA) from 1990 up to the present day), in which the shallow time depth is offset by an unprecedented corpus size and breadth of genres. This growth of corpus size leads to an increased need for more sophisticated search algorithms to automatically retrieve relevant instances from these vast corpora, and it leads to an increased need for pragmatically annotated corpora. The annotations code the contextual details in the corpus and thus make them accessible to search algorithms which are needed to retrieve pragmatic entities, such as, for instance, specific speech acts (e.g. the Sociopragmatic Corpus, Culpeper and Archer, 2008).

This trend to ever richer contextualisation of historical analysis also includes the material context. It has become widely acknowledged that meaning is communicated not only through the language of historical texts but also through their visual and physical appearance. Two previously separate research traditions, historical sociopragmatics and 'materialist philology', were brought together to examine the 'pragmatics on the page', that is, the sociopragmatic functions of the various material elements of historical texts (Carroll et al., 2013: 54-55).

The material elements of historical texts that have been examined are various. Studies have focused on paratextual features such as the layout of manuscript or printed pages, the use of space, illustrations and the choice of script or type, and how these visual elements carried meanings and were used by text producers with their readers in mind (e.g. Carroll et al., 2013, Suhr, 2011, Williams, 2013, see also contributions in Pahta and Jucker, 2011). Moreover, linguistic features have been analysed by considering the scribal context. Early modern letters, for example, show practices of collaborative authorship, which raise the question of whose language use it is that we are examining and thus call for careful distinctions between holograph (i.e. writing in the author's own hand) and scribal handwriting (e.g. Williams, 2013, Marcus, 2018). 
The philological revival has also drawn attention to easily overlooked features such as punctuation practices, and their pragmatic functions of structuring texts for their readers (e.g. Claridge and Kytö, 2020, Williams, 2013). The link between punctuation and reading practices becomes particularly evident when texts move from manuscript to print (e.g. Smith, 2017) or when present-day conventions are absent in historical texts, such as the lack of quotation marks for marking direct speech in early modern texts (e.g. Moore, 2011). The pragmatic analysis of punctuation and other scribal features, such as corrections or abbreviations, is becoming facilitated by a new generation of text editions which show new standards in historical sociopragmatics for faithful transcriptions of manuscripts and printed texts and the inclusion of facsimile images to study visual features (e.g. Kytö et al., 2011, Taavitsainen and Pahta, 2013, Rosenthal et al., 2009).

What ties all the studies together at the interface between philology and historical sociopragmatics is a broadly discursive perspective that written texts represent interactions between writers and their readers. Any textual feature, whether linguistic, visual or material, served communicative needs specific to the socio-historical contexts in which texts were produced and received. For an enhanced understanding of historical texts, it is important to describe the different 'communicative layers' and how they work together in meaning-making processes (Jucker and Pahta, 2011: 3).

\section{Conclusion}

Historical sociopragmatics has come a long way since the inception of historical pragmatics in the mid-1990s. It grew out of a merging of research interests between historical linguistics and pragmatics. It happened at a time when the first small-scale historical corpora were released and became more widely available and when pragmaticists extended their views of what was legitimate data for pragmatic theorising and analysis. Since then, the processing powers and storage capabilities of computers have increased at an unprecedented rate, which has given rise to new and exciting research opportunities. It allows for much larger datasets to be considered and it allows for more sophisticated search algorithms. At the same time, these possibilities also create new challenges. It is important to combine the large-scale diachronic investigations with detailed discursive analyses of individual communicative interactions. Discursive approaches focus on the interaction between speakers and hearers, or - in a historical context - writers and their audiences, and on the dynamic nature of linguistic units and the discursive negotiations of meanings. As illustrated in our case study, default values

and the sequential organisation of communication play an important role in the discursive negotiations of meanings as participants contest meanings that were established in previous interactions rather than referring only to the 'here and now' of the specific ongoing interaction. Capturing the dynamics between default values and their discursive readjustments as well as participants' management of social relationships and identities is what we have called the emergent third-wave approaches in historical sociopragmatics.

\section{Sources}

Dawson, J., ed. (2004/2007). The Breadalbane Collection, 1548-1583. Edinburgh: University of Edinburgh. Available at: https://www.ed.ac.uk/divinity/research/resources/breadalbane (accessed 11 April 2019). 
National Records of Scotland, Edinburgh. Papers of the Campbell Family, Earls of Breadalbane (Breadalbane Muniments), MS NRS GD112/39/3/24, MS NRS GD112/39/3/26, MS NRS GD112/39/3/27, MS NRS GD112/39/5/2.

\section{References}

Archer, D. E. (2005). Questions and Answers in the English Courtroom (1640-1760). Amsterdam/Philadelphia: John Benjamins.

Arnovick, L. K. (1999). Diachronic Pragmatics: Seven Case Studies in English Illocutionary Development. Amsterdam/Philadelphia: John Benjamins.

Bax, M. (2010). Epistolary presentation rituals: Face-work, politeness, and ritual display in Early Modern Dutch letter-writing. In J. Culpeper and D. Z. Kádár, eds., Historical (Im)politeness. Bern: Peter Lang, 37-85.

Bousfield, D. (2008). Impoliteness in Interaction. Amsterdam/Philadelphia: John Benjamins.

Brinton, L. J. (1996). Pragmatic Markers in English. Grammaticalization and Discourse Functions. Berlin: Mouton de Gruyter.

Brown, P. and S. Levinson. (1987). Politeness. Some Universals in Language Usage. Cambridge: Cambridge University Press.

Brown, R. and A. Gilman. (1989). Politeness theory and Shakespeare's four major tragedies. Language in Society, 18(2), 159-212.

Bucholtz, M. (1999). 'Why be normal?': Language and identity practices in a community of nerd girls. Language in Society, 28(2), 203-223.

Bucholtz, M. and K. Hall. (2004). Language and identity. In A. Duranti, ed., A Companion to Linguistic Anthropology. Malden, Mass.: Blackwell, 369-394.

Busse, U. (2002). Linguistic Variation in the Shakespeare Corpus: Morpho-Syntactic Variability of Second Person Pronouns. Amsterdam/Philadelphia: John Benjamins.

Campbell, A. (2002). A History of Clan Campbell: From Flodden to the Restoration. Vol. 2. Edinburgh: Edinburgh University Press.

Carroll, R., M. Peikola, H. Salmi, M.-L. Varila, J. Skaffari and R. Hiltunen. (2013). Pragmatics on the page. European Journal of English Studies, 17(1), 54-71.

Cathcart, A. (2006). Kinship and Clientage: Highland Clanship 1451-1609. (The Northern World 20). Leiden: Brill.

Chapman, S. (2011). Pragmatics. Houndmills, Basingstoke: Palgrave Macmillan.

Claridge, C. (2018). Now in the historical courtroom. Journal of Historical Pragmatics, 19(2), 223-242.

Claridge, C. and M. Kytö, eds. (2020). Punctuation in Context - Past and Present Perspectives. Berlin: Peter Lang.

Cruickshank, J. (2013). The role of communities of practice in the emergence of Scottish Standard English. In J. Kopaczyk and A. H. Jucker, eds., Communities of Practice in the History of English. Amsterdam/Philadelphia: John Benjamins, 19-49.

Culpeper, J. (1996). Towards an anatomy of impoliteness. Journal of Pragmatics, 25, 349-367.

Culpeper, J. (2009). Historical sociopragmatics: An introduction. Journal of Historical Pragmatics, 10(2), 179-186. 
Culpeper, J. (2010). Historical sociopragmatics. In A. H. Jucker and I. Taavitsainen, eds., Historical Pragmatics. Berlin/New York: De Gruyter Mouton, 69-94.

Culpeper, J., ed. (2011a). Historical Sociopragmatics. Amsterdam/Philadelphia: John Benjamins.

Culpeper, J. (2011b). Impoliteness: Using Language to Cause Offence. Cambridge: Cambridge University Press.

Culpeper, J. and D. E. Archer. (2008). Requests and directness in Early Modern English trial proceedings and play texts, 1640-1760. In A. H. Jucker and I. Taavitsainen, eds., Speech Acts in the History of English. Amsterdam/Philadelphia: John Benjamins, 45-84.

Culpeper, J., R. Crawshaw and J. Harrison. (2008). 'Activity types' and 'discourse types': Mediating 'advice' in interactions between foreign language assistants and their supervisors in schools in France and England. Multilingua, 27, 297-324.

Culpeper, J. and C. Hardaker. (2017). Impoliteness. In J. Culpeper, M. Haugh and D. Z. Kádár, eds., The Palgrave Handbook of Linguistic (Im)politeness. London: Palgrave Macmillan, 199-225.

Culpeper, J. and M. Kytö. (2010). Early Modern English Dialogues. Spoken Interaction as Writing. Cambridge: Cambridge University Press.

Dawson, J., ed. (1997). Campbell Letters 1559-1583. Edinburgh: Scottish History Society.

DOST = Dictionary of the Older Scottish Tongue. 2004/2014. University of Dundee / University of Glasgow. Available at: http://www.dsl.ac.uk/ (accessed: 11 April 2019).

Eelen, G. (2001). A Critique of Politeness Theories. Manchester/Northampton: St. Jerome Publishing.

Grainger, K. (2011). 'First order' and 'second order' politeness: Institutional and intercultural contexts. In L. P. R. Group, ed., Discursive Approaches to Politeness. Berlin: De Gruyter Mouton, 167-188.

Huang, Y. (2007). Pragmatics. Oxford: Oxford University Press.

Jacobs, A. and A. H. Jucker. (1995). The historical perspective in pragmatics. In A. H. Jucker, ed., Historical Pragmatics: Pragmatic Developments in the History of English. Amsterdam: John Benjamins, 3-33.

Jucker, A. H., ed. (1995). Historical Pragmatics: Pragmatic Developments in the History of English. Amsterdam: John Benjamins.

Jucker, A. H. (2012). 'These imputations are too common, sir': Politeness in Early Modern English dialogues: The case of Ben Jonson's Volpone, or The Fox. In G. Mazzon and L. Fodde, eds., Historical Perspectives on Forms of English Dialogue. Milano: Franco Angeli, 40-58.

Jucker, A. H. (2014). Courtesy and politeness in Sir Gawain and the Green Knight. Studia Anglica Posnaniensia, 49(3), 5-28.

Jucker, A. H. (2017). Pragmatics and language change: Historical pragmatics. In Y. Huang, ed., Oxford Handbook of Pragmatics. Oxford: Oxford University Press, 550-566.

Jucker, A. H. and M. A. Locher. (2017). Introducting Pragmatics of Fiction: Approaches, trends and developments. In M. A. Locher and A. H. Jucker, eds., Pragmatics of 
Fiction. (Handbooks of Pragmatics 12). Berlin/New York: De Gruyter Mouton, 121.

Jucker, A. H. and P. Pahta. (2011). Communicating manuscripts: Authors, scribes, readers, listeners and communicating characters. In P. Pahta and A. H. Jucker, eds., Communicating Early Manuscripts. Cambridge: Cambridge University Press, 1-10.

Jucker, A. H. and I. Taavitsainen. (2000). Diachronic speech act analysis. Insults from flyting to flaming. Journal of Historical Pragmatics, 1(1), 67-95.

Jucker, A. H. and I. Taavitsainen. (2013). English Historical Pragmatics. Edinburgh: Edinburgh University Press.

Kádár, D. Z. (2010). Exploring the historical Chinese polite denigration/elevation phenomenon. In J. Culpeper and D. Z. Kádár, eds., Historical (Im)politeness. Bern: Peter Lang, 117-145.

Kádár, D. Z., M. Haugh and W.-L. M. Chang. (2013). Aggression and perceived national face threats in Mainland Chinese and Taiwanese CMC discussion boards. Multilingua, 32(3), 343-372.

Keay, J. and J. Keay, eds. (2000). Collins Encyclopedia of Scotland. Revised edition. London: HarperCollins.

Kopaczyk, J. and A. H. Jucker, eds. (2013). Communities of Practice in the History of English. Amsterdam/Philadelphia: John Benjamins.

Kopytko, R. (1995). Linguistic politeness strategies in Shakespeare's plays. In A. H. Jucker, ed., Historical Pragmatics: Pragmatic Developments in the History of English. Amsterdam/Philadelphia: John Benjamins, 515-540.

Kytö, M. (2010). Data in historical pragmatics. In A. H. Jucker and I. Taavitsainen, eds., Historical Pragmatics. (Handbooks of Pragmatics 8). Berlin/New York: De Gruyter Mouton, 33-67.

Kytö, M., P. Grund and T. Walker. (2011). Testifying to Language and Life in Early Modern England. Amsterdam/Philadelphia: John Benjamins.

Labov, W. (1994). Principles of Language Change. Vol. 1: Internal Factors. Oxford: Blackwell.

Leitner, M. (2015). Conflicts in Early Modern Scottish Letters and Law-Courts. University of Glasgow: Unpublished PhD Thesis.

Leitner, M. (2017). Curses or threats? Debating the power of witches' words in 17thcentury Scottish courtrooms. Nordic Journal of English Studies, 16(1), 145-170.

Locher, M. A. and R. J. Watts. (2005). Politeness theory and relational work. Journal of Politeness Research, 1, 9-33.

Lutzky, U. (2012). Discourse Markers in Early Modern English. Amsterdam/Philadelphia: John Benjamins.

Marcus, I. (2018). The Linguistics of Spoken Communication in Early Modern English Writing: Exploring Bess of Hardwick's Manuscript Letters. Houndmills, Basingstoke: Palgrave Macmillan.

Marmaridou, S. (2011). Pragmalinguistics and sociopragmatics. In W. Bublitz and N. R. Norrick, eds., Foundations of Pragmatics. (Handbooks of Pragmatics 1). Berlin: De Gruyter, 77-106.

Mills, S. (2003). Gender and Politeness. Cambridge: Cambridge University Press. 
Moore, C. (2011). Quoting Speech in Early English. Cambridge: Cambridge University Press.

Nevala, M. (2004). Address in Early English Correspondence: Its Forms and SocioPragmatic Functions. Helsinki: Société Néophilologique.

Nevalainen, T. and H. Raumolin-Brunberg. (1995). Constraints on politeness: The pragmatics of address formulae in early English correspondence. In A. H. Jucker, ed., Historical Pragmatics: Pragmatic Developments in the History of English. Amsterdam: John Benjamins, 541-601.

OED = Oxford English Dictionary. 1899-2019. Oxford: Oxford University Press. Available at: http://www.oed.com/ (accessed: 11 April 2019).

Pahta, P. and A. H. Jucker, eds. (2011). Communicating Early Manuscripts. Cambridge: Cambridge University Press.

Petikó, M. (2017). Discursive (re)construction of 'witchcraft' as a community and 'witch' as an identity in the eighteenth-century Hungarian witchcraft trial records. Journal of Historical Pragmatics, 18(2), 214-234.

Reutner, R. (2016). Politisch-parlamentarisches Sprachhandeln am Beispiel der Sprachenfrage in der österreichisch-ungarischen Monarchie. Dargestellt am Sprechhandlungstyp Drohung. In P. Ernst and M. Werner, eds., Linguistische Pragmatik in Historischen Bezügen. Berlin/Boston: De Gruyter, 313-324.

Rosenthal, B., G. A. Adams, M. Burns, P. Grund, R. Hiltunen, L. Kahlas-Tarkka, M. Kytö, M. Peikola, B. C. Ray, M. Rissanen and M. K. Roach, eds. (2009). Records of the Salem Witch-Hunt. Cambridge: Cambridge University Press.

Sairio, A. (2017). 'Now to my distress': Shame discourse in eighteenth-century English letters. Journal of Historical Pragmatics, 18(2), 295-314.

Schwenter, S. A. and E. C. Traugott. (1995). The semantic and pragmatic development of substitutive complex prepositions in English. In A. H. Jucker, ed., Historical Pragmatics: Pragmatic Developments in the History of English. Amsterdam: John Benjamins, 243-273.

Smith, J. J. (2012). Older Scots: A Linguistic Reader. Edinburgh: The Scottish Text Society.

Smith, J. J. (2017). From secreit script to public print: Punctuation, news management and the condemnation of the Earl of Bothwell. Huntington Library Quarterly, 80(2), 223-238.

Spencer-Oatey, H., ed. (2002). Culturally Speaking: Managing Rapport through Talk across Cultures. Reprint. London/New York: Continuum.

Spencer-Oatey, H. (2005). (Im)politeness, face and perceptions of rapport: Unpackaging their bases and interrelationships. Journal of Politeness Research, 1, 95-119.

Spencer-Oatey, H. (2007). Theories of identity and the analysis of face. Journal of Pragmatics, 39, 639-656.

Suhr, C. (2011). Publishing for the Masses: Early Modern English Witchcraft Pamphlets. Helsinki: Société Néophilologique.

Taavitsainen, I. (2017). Meaning-making practices in the history of medical English: A sociopragmatic approach. Journal of Historical Pragmatics, 18(2), 252-270.

Taavitsainen, I. and P. Pahta. (2013). The Corpus of Early English Medical Writing (1375-1800) - a register-specific diachronic corpus for studying the history of scientific writing. In A. Meurman-Solin and J. Tyrkkö, eds., Principles and 
Practices for the Digital Editing and Annotation of Diachronic Data. (Studies in Variation, Contacts and Change in English 14). University of Helsinki:

VARIENG. Available at:

http://www.helsinki.fi/varieng/series/volumes/14/index.html (accessed 11 April 2019).

Williams, G. T. (2013). Women's Epistolary Utterance: A Study of the Letters of Joan and Maria Thynne, 1575-1611. Amsterdam/Philadelphia: John Benjamins.

Włodarczyk, M. (2013). British colonial office correspondence on the Cape Colony (1820-1821): Metatextual keywords vs. analytic categories. Poznań Studies in Contemporary Linguistics, 49(3), 399-428.

Włodarczyk, M. and I. Taavitsainen. (2017). Introduction: Historical (socio)pragmatics at present. Journal of Historical Pragmatics, 18(2), 159-174. 